\title{
THE COLOR OF WINE: A HISTORICAL PERSPECTIVE. I. SPECTRAL EVALUATIONS.
}

\author{
F.J. HEREDLA and M. GUZMÁN-CHOZAS ${ }^{1}$ \\ Department of Nutrition and Food Science, Faculty of Pharmacy \\ University of Sevilla, 41012 Sevilla, Spain.
}

Accepted for Publication July 23, 1993

\begin{abstract}
In the 1930s trade transactions required that the color of wine be more rigidly specified. The wine-colorimeter was useful with this purpose. Intensity of color was the first property to be considered. From the beginning of this century visual comparisons of wines with standard mixtures of dyes or colored substances (potassium permanganate and dichromate) were made. Later photometric studies (absorption curves) were developed. Maxima and minima in the absorption curve were defined, as well as their relationships. Recently, it has been shown that absorbance values at given wavelengths and luminosity are well correlated.
\end{abstract}

\section{INTRODUCTION}

Early in the 1930s interest increased in the measurement of the color of red wines. Roos (1930) explained the importance of color intensity of red wines from the point of view of trade. When alcoholic percentages were the same, the wines with a stronger color were the more expensive. Furthermore, the author predicted the importance of wine color measurements in the future. He referred to the oldest scales for evaluating color, as Chevreul's method, where five purple red and three red shades were observed. On the other hand, Salleron (Roos 1930) devised the Wine-colorimeter to measure hue and color intensity of wines; it was designated a Chromatometer, a new apparatus based on polarimetry, which allowed the obtaining of data on the quality and intensity of color. The instrument made possible measurement of the hues from violet to yellow, red, or in other words, all the possible colors of red wines.

Hue was then considered a property of minor importance, and efforts were principally concentrated on color intensity measurements. It was considered indispensable to define a unit of low magnitude for color, so that all wines

'Correspondence should be addressed to: Prof. Dr. M. Guzmán-Chozas.

Journal of Food Quality 16 (1993). 429-437. All Rights Reserved.

oCopyright 1994 by Food \& Nutrition Press, Inc., Trumbull, Connecticut. 
would be greater in magnitude and handling would thus have better understanding. Intensity was measured through necessary wine dilution to obtain the degree of coloration. According to Roos (1930) the first attempt in this way was carried out by Pietri in 1900; he used a mixture of Fucsina and Victoria Yellow (trinitrocresol), but it was unstable to light. Later, the mixture, $\mathrm{KMnO}_{4}$ $\mathrm{K}_{2} \mathrm{Cr}_{2} \mathrm{O}_{7}$, was proposed with success, because it is possible to obtain the different hues of red wines, from red-violet $\left(\mathrm{KMnO}_{4}\right)$ to yellow-orange $\left(\mathrm{K}_{2} \mathrm{Cr}_{2} \mathrm{O}_{7}\right)$. A "good" red wine was specified to be more than ten "colors", i.e. dilution must be at least nine parts of water to one part of wine to obtain the intensity established for unit "color". Later this procedure was completed by Vogt (1935), and some conclusions about chromatic properties and geographic origins of wines were possible. Several authors had proposed other standard solutions that improved the sensitivity in comparisons of red wines (Kielhofer 1944; Wobish and Schneyder 1955).

The method proposed by Roos (1930) remained for some time as the usual one. But other methods based on colorimetric or photometric techniques arose. Montequi (1933) carried out the earliest studies on absorption curves, or "color curves", taking as reference those of "Rojo Burdeos" a standard dye. The photoelectric cell as an objective discriminant in substitution of the human eye was proposed; and "ROB" was defined as a color unit (Fauré and Pallu 1935):

$$
\mathrm{ROB}=\mathrm{K} \cdot \mathrm{D}
$$

where $\mathrm{K}$ is a constant which was obtained when the colorimeter was calibrated with Crystal Violet, and D is the optical density at a given wavelength (usually, $460 \mathrm{~nm}$ ). Wines could be classified by means of "ROB":
(1) Rose wines:
$15-50$ "ROB"
(2) Red wines:
50-115 "ROB"
(3) 'Teinturiers': ' 115-600 "ROB"

New applications about the spectral study of wines next appeared (Casamada 1931; Boutaric et al. 1937; Korotkevich 1951), and further conclusions were derived. The maximum of spectral absorption for red wines was established $\left(\lambda_{\max } \approx 520 \mathrm{~nm}\right)$; the ratio $\mathrm{A}_{420} / \mathrm{A}_{520}$ was demonstrated to be significant for characterizing red wine color; a new concept named "underground color", the relationship

$$
\frac{A_{\text {s2s }}(\text { wine })}{A_{\text {s2 }}(\text { standard })} \times 55
$$


was stated, when wine is compared with a standard solution of $\mathrm{CoSO}_{4} \cdot 7 \mathrm{H}_{2} \mathrm{O}$. The evidence of an higher maximum wavelength for red wines than for rose wines was demonstrated too (Amerine and Winkler 1941).

\section{ABSORPTION CURVES}

In the beginning, the UV absorption curves of the wines were plotted to detect possible adulterations. Comparisons between wine musts and standard synthetic dye dilutions were carried out (Casamada 1931). Montequi (1933) studied for the first time absorption curves of certified and common red wines, and he compared them with "Rojo Burdeos". Boutaric et al. (1937) carried out studies on the spectral characteristics in red wines; the maxima and minima of absorption curves of six typified French wines were obtained. Their observations can be summarized as follows:

(1) usually an absorption maximum at $520 \mathrm{~nm}$ was detected

(2) the absorbance ratio $A_{480} / A_{640}$ was relevant to typify the wine color

(3) although Fauré and Pallu (1935) proposed a simple rule for the color of mixed wines, Boutaric et al. (1937) demonstrated that the coupage obtained was lighter than expected because of the colloidal character of coloring matters in wines

(4) if the $\mathrm{pH}$ was deliberately increased with $\mathrm{NaOH}$, an absorption minimum at $480 \mathrm{~nm}$ appeared. The maximum of $520 \mathrm{~nm}$ was displaced to higher wavelength (bathochromic shift). The ratio $\mathrm{A}_{480} / \mathrm{A}_{640}$ decreased.

Korotkevich (1951) described the characteristic absorption spectra of white and red wines. Samples were diluted before they were measured, and absorption maxima at 430 and $530 \mathrm{~nm}$ were obtained for white and red wines, respectively. As Boutaric et al. (1937) demonstrated, the dilution of wine sample results is inappropriate. It is necessary to use cells of different path lengths.

Tashkova and Goranov (1967) investigated spectrophotometrical studies with distillates of wines, and they noted that specific extinctions at 360 and $420 \mathrm{~nm}$ must be considered. Kampis and Ásvany (1985) correlated lightness with $\mathrm{A}_{520}$, and they obtained a favorable correlation coefficient $\left(\mathrm{r}^{*}=0.9, \mathrm{n}=74\right.$ samples) in a double logarithmic representation:

$$
\log \mathrm{A}_{520}=1.501-1.02 \log \mathrm{Y}
$$

where $\mathrm{Y}=$ luminosity. 
Sudraud (1958) tested the absorption curves of red wines, and he reported characteristic maximum and minimum wavelengths. The absorbances at 520 and $420 \mathrm{~nm}$ offered a definition for the hue of color or "tint". The OIV Rapid Method is based on the index that Sudraud proposed to define color intensity. Hue is expressed by the angle of the line that connects the points in the absorption curve which correspond to $\lambda_{d}=420$ and $\lambda d=520 \mathrm{~nm}$. This procedure was recognized by Mareca (1964) and Harvalia (1967). The tangent of this angle is given by the difference $\left(\mathrm{A}_{520^{-}} \mathrm{A}_{420}\right)$ (Fig. 1). Angles between $0^{\circ}$ and $51^{\circ}$ correspond to red wines; angles between $52^{\circ}$ and $80^{\circ}$ concern purple red wines. Negative angles mean that it is a question of spoiled wines (oxidized wines, polymerization of coloring matter) or any other circumstances that may be conductive of pale colors. Yellow contribution to the full color of wines is better defined by the ratio $A_{420} / A_{520}$ than by the difference $A_{520}-A_{420}$. For young red wines this ratio was $0.5-0.7$, and it can reach a value of 1.0-1.2 for aged wines (Ribéreau-Gayon et al. 1980).

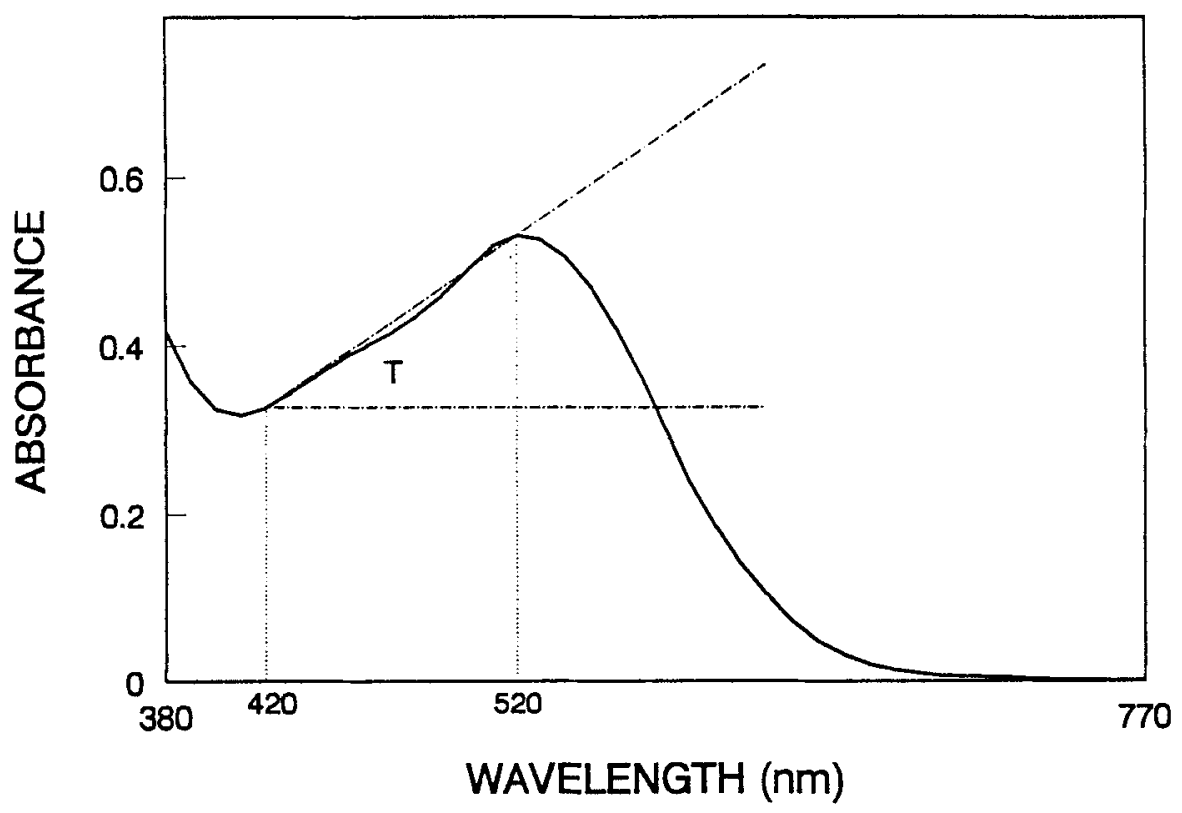

FIG. 1. SPECTRAL SIGNIFICANCE OF TINT, T 
Taking into account the absorption spectrum shape, Glories (1984) proposed the red proportion, $\mathrm{dA} \%$, contribution to the full color of wines to be:

$$
d A 8=\frac{100}{A_{5 x}}\left[A_{5 x 0}-\frac{\left(A_{500}+A_{800}\right)}{2}\right]
$$

In fact, this formula emerges from a simple analytical mathematical treatment of the spectral curve (Fig. 2); dA\% corresponds to the color contribution of the "flavilium" cations of the free and combined anthocyanins. When the absorption spectrum shows a narrow maximum band, dA\% increases (60-80\%), indicating a bright red color. When the absorption maximum is flatter and $\mathrm{dA} \%$ is less than $40 \%$, the color of wine is less a pure red.

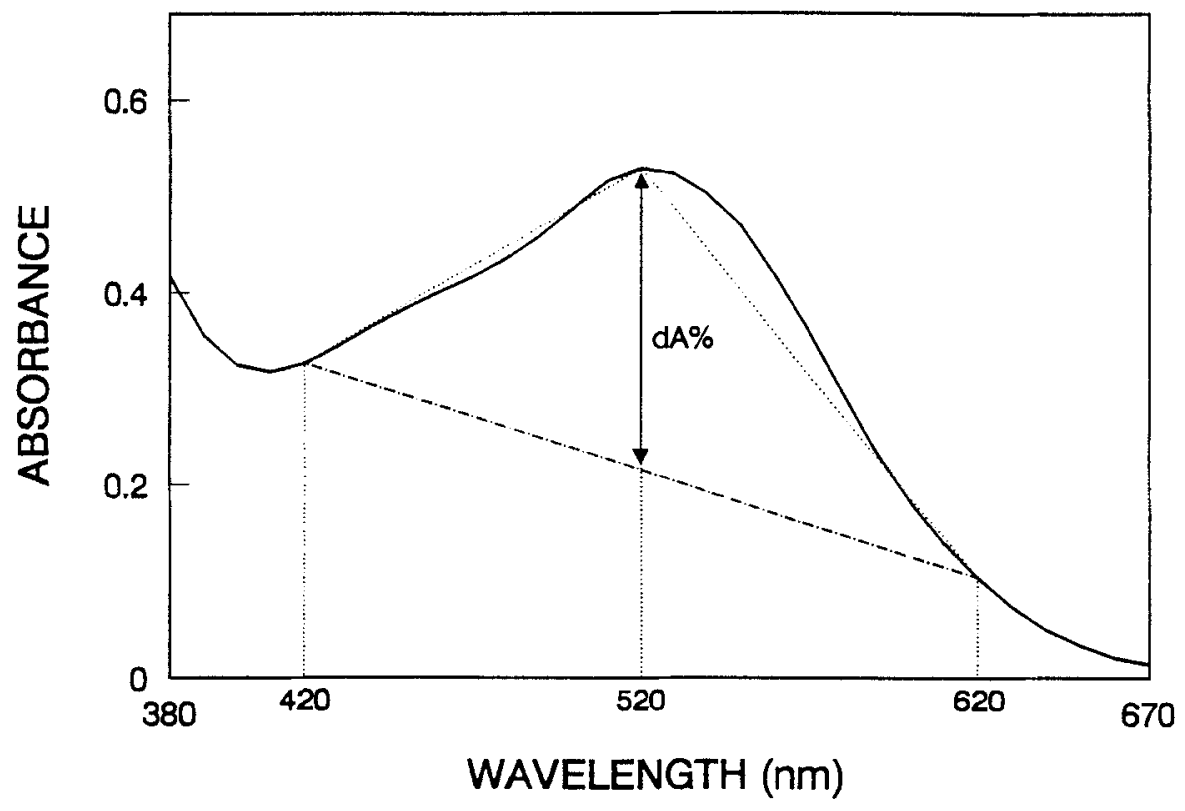

FIG. 2. SPECTRAL SIGNIFICANCE OF RED PROPORTION, DA\% 


\section{COLOR INTENSITY}

From the objective basis of knowledge of the color of wines, a definition of color intensity have been attempted as a function of certain wavelengths selected from the absorption spectra of red and white wines. Korotkevich (1951) proposed the recording of absorbances at $430 \mathrm{~nm}$ (white wines) and $530 \mathrm{~nm}$ (red wines), previously diluted, to obtain relative intensities of color. These absorbances values, corrected by dilution, could give a useful approach to the amount of colored substances present in wines, if multiplied by the Neubaüer-Lowenthal constant (Lowenthal 1877), used for tannin determinations.

A few studies about color evaluation of white wines have been carried out. Their dominant color is included between golden yellow and greenish yellow, with a maximum wavelength between $400-480 \mathrm{~nm}$. In coloring matter investigations, a relevant UV absorption at $270-280 \mathrm{~nm}$ was found for white wines. There are many studies on red wines color, and in particular on intensity and hue. Sudraud (1958) tested the absorption curves of red wines, especially during the aging processes, an important factor. Young red wines showed an absorption maximum at $520 \mathrm{~nm}$ in the red zone, due chiefly to anthocyanins content. There are thus three absorption maxima: 520,420 and $280 \mathrm{~nm} . \mathrm{A}_{520}$ decreases and $A_{420}$ increases when dealing with aged red wines, more than ten years old (Fig. 3). This causes an evolution towards red-orange hues. In accordance with these findings, Sudraud proposed the sum $A_{420}+A_{520}$ as a satisfactory expression for color intensity. A numerical computation of color intensity can be made through the intersections or overlapings of spectral curves when evolution upon the aging of wines occurs. The original purple color became brown owing to enzymatic oxidation of anthocyanins and later condensation of decomposition products (Lemperle and Kerner 1968).

González (1980) used the formulae by Sudraud to compute color intensity in Rioja red wines by considering $A_{520}$ as representative of absorption by anthocyanins and $\mathrm{A}_{420}$ as the absorption due to tannins and flavonols. He obtained spectral absorption values equal or less to 10 absorbance units for Rioja Baja wines and greater than 4 units for Rioja Alavesa wines. The author showed some influences between the color intensity and climatic conditions, alcoholic degree and $\mathrm{pH}$. Ruiz (1983) determined in Rioja grapes and musts that $\mathrm{pH}$, refraction index, polyphenoloxidase activity, potassium and tartaric acid contents could be related to color intensity. The agreement between anthocyanic pigments and color intensity have been studied (Vasileva and Goranov 1983; Gil and Gómez-Cordovés, 1985). Polymerization and condensation of anthocyanins and polyphenols, during the aging process of wines, caused a decrease of color 


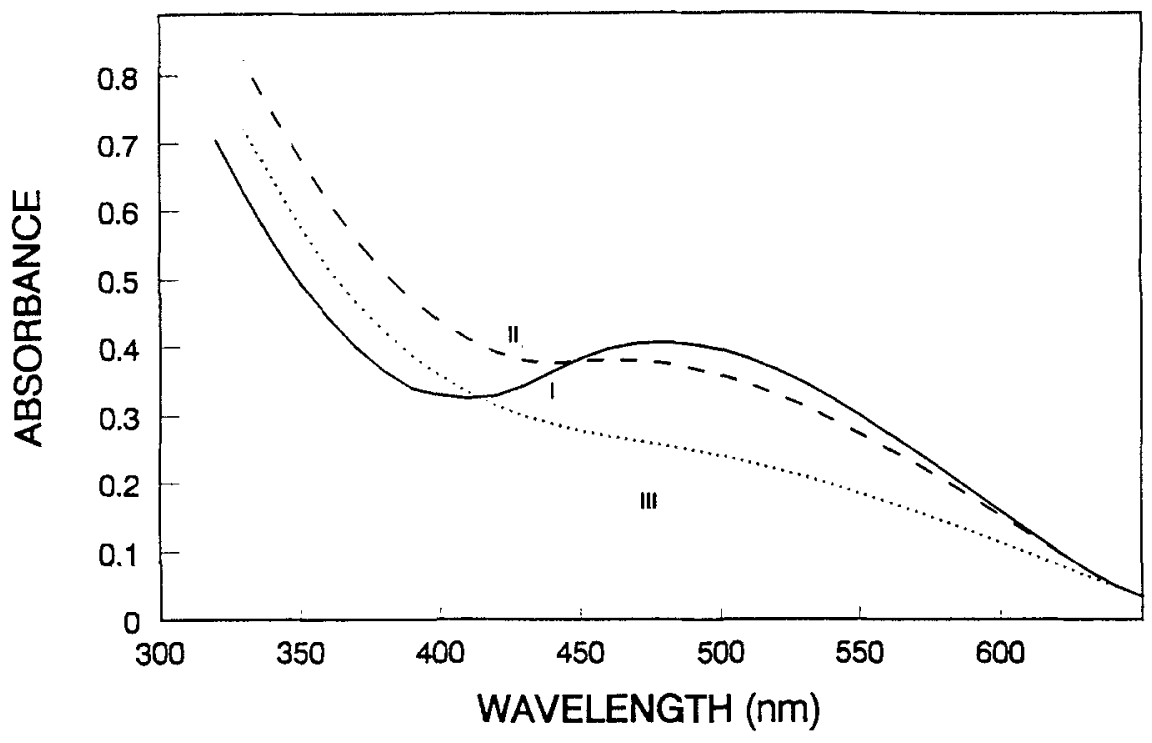

FIG. 3. ABSORPTION SPECTRA FROM THREE DIFFERENT AGED WINES (I: 1 YEAR; II: 5 YEARS; III: 10 YEARS) (Sudraud 1958)

intensity. Kerenyi and Kampis (1984) have demonstrated a strong correlation ( $\mathrm{r}^{*}$ $>0.95$ ) between color intensity and sensorial tests (triangular and ranking tests). They proposed the equation:

$$
\mathrm{n}=23 \cdot \log \left(\mathrm{A}_{420}+\mathrm{A}_{520}\right)
$$

where " $n$ " was the average of scores obtained by the sensory tests and it was considered as a new parameter related to the logarithm of color intensity. Color intensity defined by this formula can acquire a negative value; but rose and red wines show $\log$ (color intensity) values from 0 to 20 . As linearity was observed up to $" n "=27$, it can be useful in the color characterization of all the red wines.

Glories (1984) observed that in color evaluation distinctness between young and aged wines is necessary. For young wines (less than a year old) if only $\mathbf{A}_{420}$ and $\mathrm{A}_{520}$ are considered, they are not sufficient. Consideration of the blue component $\left(\mathrm{A}_{620}\right)$, which was attributed to quinonic forms of free and combined 
anthocyanins was proposed. This novel component is very important in wines with a pH near 4. Glories (1984) proposed the Modified Color Intensity (CI') test as the sum of the three absorbances:

$$
\mathrm{Cl}^{\prime}=\mathrm{A}_{420}+\mathrm{A}_{520}+\mathrm{A}_{620}
$$

Partial contributions to the full color were defined as:

$$
\begin{array}{lll}
\text { (1) yellow: } & \mathrm{A}_{420}(\%)=\mathrm{A}_{420} \cdot 100 / \mathrm{CI} \\
\text { (2) red: } & \mathrm{A}_{520}(\%)=\mathrm{A}_{520} \cdot 100 / \mathrm{CI} \\
\text { (3) blue: } & \mathrm{A}_{620}(\%)=\mathrm{A}_{620} \cdot 100 / \mathrm{Cl}
\end{array}
$$

Wines appear more saturated in color as the blue component, $A_{620}(\%)$, increases.

In conclusion, the methods found in direct spectral evaluations, as well as related parameters, offer an interesting chance for the assessment of color evolution of wines. However, these methods suffer from an unavoidable failure to define the color. They are very helpful, owing to their simplicity, in the routine measures made at winecellars. But if our aim be the strict chromatic characterization of color, indispensable is the application of trichromatic methods, dealt with in a following article.

\section{REFERENCES}

AMERINE, M.A. and WINKLER, A.J. 1941. Color in California wines. IV. Production of pink wines. Food Res. 6, 1-14.

BOUTARIC, A., FERRE, L., ROY, M. 1937. Recherches spectrophotometriques sur la coleur des vins. Ann. Fals. 30, 196-209.

CASAMADA, R. 1931. Absorption spectra in the ultra-violet region and detection of artificial coloring matter in wines. Mem. Acad. Cienc. Artes Barcelona 22(12), 251-256.

FAURE, A. and PALLU, R. 1935. Measure de la coloration des liquides. Ann. Fals. 28, 5-9.

GIL, C. and GÓMEZ-CORDOVÉS, C. 1985. El contenido en polifenoles totales, catequinas, o-difenoles y el color, de vinos, como característica varietal. Anal. Bromatol. 37(1), 153-159.

GLORIES, Y, 1984. La couleur des vins rouges. 2e partie. Mesure, origine et interpretation. Connaiss. Vigne Vin 18(4), 253-271.

GONZÁLEZ, M. 1980. Estudio varietal de la materia colorante en los vinos tintos de Rioja. Sem. Vitivinic. 35(1758), 1231-1233. 
HARVALIA, A. 1967. Office Internationale de la Vigne et du Vin, Méthode d'analyse no. 232.

KAMPIS, A. and ASVANY, A. 1985. Characterization of the colour of red wines by trichromatic values. Acta Alimentaria 14(4), 319-329.

KERENYI, A. and KAMPIS, A. 1984. Comparison between the sensorially established and instrumentally measured colour of red wine. Acta Alimentaria 13(4), 325-342.

KIELHOFER, E. 1944. Color measurement in red wines. Wein u. Rebe. 26, $1-14$.

KOROTKEVICH, A.V. 1951. Spectrophotometric determination of the color of wine. Vinodelie i Vinogradarstvo SSSR 11(1), 20-22.

LEMPERLE, E. and KERNER, E. 1968. Color of red wine. I. Color intensity measurement. Wein Wiss. 23(7-8), 281-294.

LOWENTHAL, J. 1877. Z. Anal. Chem. 16, 33-48.

MARECA, I. 1964. Office Internationale de la Vigne et du Vin, Méthode d'analyse no. 62.

MONTEQUI, F. 1933. El color del vino. Anales Real Soc. Españ. Fís. Quím. 31, 663-668.

RIBÉREAU-GAYON, J., PEYNAUD, E., SUDRAUD, P. and RIBÉREAUGAYON, P. 1980. Ciencia y Técnicas del vino. I. Análisis y control de los vinos. Ed. Hemisferio Sur, S.A., Buenos Aires.

ROOS, L. 1930. Mesure de la couleur des vins rouges. Ann. Fals. 23, 207-211.

RUIZ, M. 1983. Evaluación cromática de uvas de Rioja. Sem. Vitivinic. 1904, 404-407.

SUDRAUD, P. 1958. Interpretation des courbes d'absorption des vins rouges. Ann. Technol. Agr. 7, 203-208.

TASHKOVA, A. and GORANOV, N. 1967. Spectrophotometric measurement of the color of wine and wine distillate. Prom, Sofiya 9, 53-60.

VASILEVA, B. and GORANOV, V. 1983. Relation of color to the anthocyanin and polyphenol content of red wine. Lozar. Vinar. 32(7), 24-27.

VOGT, E. 1935. Untersuchungen uber der Rotweine. Wein u. Rebe 17, 93-101. WOBISH, F. and SCHNEYDER, J. 1955. Determination of the color of red wine. Mitt. Rebe u. Wein (Klosterneuburg) 5, 49-52. 